\title{
Back from the Crocodile's Belly: Christian formation meets indigenous resurrection
}

\begin{tabular}{|c|c|}
\hline \multicolumn{2}{|c|}{$\begin{array}{l}\text { Author: } \\
\text { S. Lily Mendoza }\end{array}$} \\
\hline $\begin{array}{l}\text { Affiliations: } \\
{ }^{1} \text { Department } \\
\text { Communicatic } \\
\text { Journalism, O } \\
\text { University, Un }\end{array}$ & $\begin{array}{l}\text { nand } \\
\text { ited States }\end{array}$ \\
\hline \multicolumn{2}{|c|}{$\begin{array}{l}{ }^{2} \text { Department of Practical } \\
\text { Theology, Faculty of } \\
\text { Theology, University of } \\
\text { Pretoria, South Africa }\end{array}$} \\
\hline \multicolumn{2}{|c|}{$\begin{array}{l}\text { Research Project Registration: } \\
\text { Project Leader: S.F. de Beer (D) } \\
\text { Project Number: } 86233689\end{array}$} \\
\hline \multicolumn{2}{|c|}{$\begin{array}{l}\text { This research is part of the } \\
\text { research project, 'Social } \\
\text { Justice and Reconciliation', } \\
\text { which is directed by Dr } \\
\text { Stephan de Beer, Director of } \\
\text { the Centre for Contextual } \\
\text { Ministry and member of the } \\
\text { Department of Practical } \\
\text { Theology, Faculty of Theology, } \\
\text { University of Pretoria. }\end{array}$} \\
\hline \multicolumn{2}{|c|}{$\begin{array}{l}\text { Corresponding author: } \\
\text { S. Lily Mendoza, } \\
\text { mendoza@oakland.edu }\end{array}$} \\
\hline $\begin{array}{l}\text { Dates: } \\
\text { Received: } 16 \text { I } \\
\text { Accepted: } 15 \\
\text { Published: } 17\end{array}$ & $\begin{array}{l}\text { May } 2017 \\
\text { uly } 2017 \\
\text { Nov. } 2017\end{array}$ \\
\hline \multicolumn{2}{|c|}{$\begin{array}{l}\text { How to cite this article: } \\
\text { Lily Mendoza, S., 2017, 'Back } \\
\text { from the Crocodile's Belly: } \\
\text { Christian formation meets } \\
\text { indigenous resurrection', HTS } \\
\text { Teologiese Studies/ } \\
\text { Theological Studies 73(3), } \\
\text { a4660. https://doi.org/ } \\
\text { 10.4102/hts.v73i3.4660 }\end{array}$} \\
\hline \multicolumn{2}{|c|}{$\begin{array}{l}\text { Copyright: } \\
\text { (C) 2017. The Authors } \\
\text { Licensee: AOSIS. This } \\
\text { is licensed under the } \\
\text { Creative Commons } \\
\text { Attribution License. }\end{array}$} \\
\hline \multicolumn{2}{|l|}{ Read online: } \\
\hline 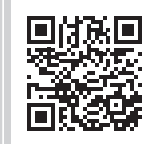 & $\begin{array}{l}\text { Scan this QR } \\
\text { code with your } \\
\text { smart phone or } \\
\text { mobile device } \\
\text { to read online. }\end{array}$ \\
\hline
\end{tabular}

Undoing all forms of domination - including, in particular, religious domination - remains a crucial imperative of our time, given that domination constitutes a spirit-killing dynamic that distorts, oppresses and throws living beings (both human and non-human alike) out of synch with themselves. One form of domination in colonial contexts is the totalising claim to a monopoly of 'the' truth that effectively delegitimises and demonises all other ways of seeing the world. This essay grapples with the question: What happens when the 'One True Story' encounters other faith stories? Riffing off my (coedited) anthology, Back from the Crocodile's Belly: Philippine Babaylan Studies and the Struggle for Indigenous Memory (dedicated to the memory of the Filipino indigenous women and men healers impaled on stakes by early Spanish missionaries and left on river banks for crocodiles to feast on), I narrate my personal journey growing up as a Filipina Methodist pastor's kid, becoming a born-again believer and an aspiring Christian missionary trained by Philippine Inter-Varsity Christian Fellowship and the Navigators, and belatedly coming to grips with my relationship to my country's colonial history and its consequences for me and my people's struggle for wholeness and authenticity. What happens when my wholly formed Christian subjectivity becomes challenged by the resurrecting call of spirit to indigenous and earth well-being? Informed by a multilayered cultural memory, I trace my faith learnings from an encounter with deep ancestry in the 'belly of the beast' and its larger significance for today's social movement struggles for sustainability and global coexistence.

\section{Introduction}

In this essay, I approach the question of interreligious encounter through a mode of narration known as ethnoautobiography. Designed by Kremer and Jackson-Paton (2014), ethnoautobiography uses an indigenously grounded form of personal storytelling as a means of restoring wholeness and reconnection to the alienated modern self. Mendoza and Kinefuchi (2016) call it 'an approach to decolonization and reclamation of the indigenous self [that] ... (re-)connects the atomized individual to place, history (including stories and myths), nature, spirit, ancestry (indigenous origins), and community ...' (pp. 278-279). In contrast to mere autobiography, ethnoautobiography seeks to bring about the healing of the 'dissociative and objectifying construction of self and reality' noted to define the colonised modern self (Kremer 2003:2).

The story that follows then is an ethnoautobiographical narration of one Filipina born-again Christian's decolonisation and indigenous reclamation journey, facilitated by her belated encounter with the repressed stories and histories of her people previously eclipsed by the all-powerful telling of a single universalising and universalised Story (with a capital 'S') - that of Christianity.

\section{Christian formation and root disconnection}

This essay is based on a talk I was invited to deliver at the Nagel Institute for World Christianity at Calvin College in 2013. Its writing followed at the heels of a book launch of an anthology I coedited with the title, Back from the Crocodile's Belly: Philippine Babaylan Studies and the Struggle for Indigenous Memory (2013). The term 'babaylan' refers to the indigenous healing tradition that among our various tribes in the Philippines is known by the differing names of mumbaki, dawac, ma-aram, catalonan, beliyan, balyan, baylan, patutunong, and so on. The book's introduction lays out the history referenced in the book's title (and now iterated for this piece):

A story is told that when the Spaniards (who colonized the Philippine islands beginning in the 16th century) began to understand the power and potency of the babaylan, they so feared the latter's spiritual prowess that they not only killed many of them but in some instances, fed them to crocodiles to ensure

Note: The collection entitled 'Spirit rising: tracing movements of justice', forms part of the 'Faith in the City' research project, hosted by the Centre for Contextual Ministry in the Faculty of Theology, University of Pretoria. Some of the articles were papers presented at the Biennial Consultation on Urban Ministry, hosted by the Institute for Urban Ministry, in collaboration with other organizations, from 17-20 August 2016. The theme of this Consultation was '\#We must rise: healers - dreamers-jesters'. 
their total annihilation. While appearing in the archive primarily in connection with a 1663 babaylan uprising in a Visayan town (where the corpses of a babaylan charismatic rebel leader and his followers were impaled on bamboo stakes and deliberately placed on the mouth of a river to be eaten by crocodiles), the story captures a broad truth: colonial violence did consume indigenous culture [as] the 2001 account of religious historian Carolyn Brewer details the systematic demonization of these indigenous healers and their ostracism and social 'dismemberment' as brujas or witches). The colonial enterprise was indeed a ravenous maw. Yet, the babaylan tradition never really died; it remained alive inside the colonial religious infrastructure. Across the centuries, its whispers and ache, its raw force and quiet upwellings, continue to speak. (Mendoza \& Strobel 2013:13-14)

I had not known of this healing tradition among our indigenous people - except as 'the work of the devil and of evil spirits' and, most of their healing work, as based on nothing more than superstitious belief. You see, I grew up a pastor's kid. My father was one of the early converts to Methodism brought over to the Philippine shores at the turn of the 20th century as part of America's 'civilising mission'. Although my mother was raised Roman Catholic, she quickly converted as soon as she married my dad and became our local church organist. Embedded in a mostly Catholic neighbourhood, what served as our family's alternative community was the local United Methodist church. We had a number of American missionaries become close family friends and we six siblings invariably became leaders of our local Methodist Youth Fellowship.

By the time I got to the University of the Philippines where I studied, I became a born-again Christian through the witness of a local chapter of the Inter-Varsity Christian Fellowship (IVCF) on campus. IVCF was a highly intellectual Oxfordoriginated movement and my involvement became a lifetransforming experience for me, equipping me with a comprehensive world view that pretty much explained how the world works, what life's purpose was, what the problem of humankind was and what was the path to salvation. Having a very strong left brain, I devoured Christian apologetics, sat in biblical hermeneutics classes at the Asian Theological Seminary and the Alliance Biblical Seminary, immersed myself in bible study and discussion groups with brilliant mentors and elders and subsequently became part of the original cohort that founded an outfit called the Institute of Studies for Asian Church and Culture (ISACC) dedicated to the faithful incarnation of the gospel within the Asian context.

For more than three decades, discipling the intelligentsia for Christ became my life's great adventure. Working as a technical researcher and writer at the Philippine Center for Advanced Studies at the University of the Philippines, I led a group of brilliant doctoral students either working in the various disciplines or preparing for diplomatic careers in biblical integration, which meant, among others, helping them look at their respective areas of studies or vocations from a strictly biblical perspective. My own master's thesis in Philippine Studies looked at the dynamics of Christian transculturation in a nationalist version of the Methodist church - the Iglesia Evangelica Metodista en Las Islas
Filipinas (IEMELIF), using mostly missiological literature such as the writings of Nida and Taber (1969) and Kraft (1979).

But while I was good at what I did and deemed my life - as a clandestine missionary among the intelligentsia - as full of meaning and purpose, unbeknownst to many, I suffered from a persistent malaise that plagued me from as far back in my childhood as I could remember. This had to do with a continuing struggle with a low self-esteem and deep-seated insecurity, that at some point, led me to seek discipleship with another Christian organisation, the Navigators, which was known for being good at discipling the whole person, not just the intellect. But that, too, failed to make a dent on my psychic disease despite years of humbly submitting myself to the tutelage of spiritual mentors and living communally in a home for $24 / 7$ for what was called 'life-to-life spiritual osmosis'.

After finishing my master's studies at the same university where I worked and conducted most of my evangelism and discipling, I received an invitation to join Inter-Varsity staff full time. Although I had longed then for nothing more than to do mission work full time, a scrupulous part of me was also aware of the glaring split I experienced between my outward gifting and another part of me that constantly cringed in shame, that doubted my integrity and that was constantly asking for forgiveness and apologising for not measuring up somehow. It became so that there were times I even contemplated ending my life. The mystery of why, despite my embrace of the teaching of God's unconditional love, I could not feel whole inside would haunt me no matter my earnestness in wanting to give my life to God and his service. Up until then, the dutiful ingestion of the ideology of individualism made my lingering malaise, as far as my scrupulous conscience was concerned, simply a matter of my own personal problem and therefore my own personal responsibility. I felt trapped and claustrophobic, my soul hemmed in on all sides and unable to breathe free even while outwardly I was deemed flourishing and 'successful'. I kept a journal of prayers that begged for God to heal me in my deepest parts. I memorised the verses that said 'a bruised reed he will not break; a dimly burning wick he will not quench' and 'my grace is sufficient for you, for my power is made perfect in weakness', and so on, yet the inner torment continued and I found no relief.

\section{Root encounter ${ }^{1}$}

It was not until a graduate course in the humanities, titled, 'The Image of the Filipino in the Arts', that I would find the key to my mysterious self-sabotaging syndrome. The class was taught by an ethnomusicology professor who conducted first-hand research into the arts of our ethnolinguistic communities that were relatively less penetrated by colonisation, missionisation and modern development and that still retained much of their land-based cultures and traditions. In the class, we were introduced to these tribal communities' intricate weaving designs, the wild vibrant colours of their textiles, their basketry, dances, songs, chants and epic oral narrations - and what these expressed in terms 1.A version of this story appears in my various writings. 
of a different way of being. For the first time, I encountered the supple world of non-individualistic interconnectedness, the delicate sensitivity of kapwa (i.e. the concept of shared being), the generosity of community, the lack of divide between the material and the spirit world, the openness of loob (or inner being), the gracious receiving of gifts of beauty and creativity from the other world through dreams, visions and the power of ritual.

I recall coming out of every class session bawling my heart out, walking back to my dorm room in tears, not knowing what it was that hit me from all the innocent descriptions of those indigenous works of art, overcome by very powerful emotion. Only later would I come to understand the meaning of those tears, that they were tears of recognition. Here at last is a different mirror held up to me. The Brazilian educator Paolo Freire once remarked in an interview that when all the authoritative representations around you have nothing to do with your reality, it is like looking into a mirror and finding no one. And sitting in that class and being introduced for the first time to the unique ways of being of our indigenous peoples talked about not in a degrading, primitivising and insulting way, but in recognition of their true beauty, nobility and grace, I saw myself. No longer would the intuitive world I sensed I had always shared with the creators of those arts but had been forced to repress in favour of the purportedly superior world of the colonial masters again appear in my eyes mangled and distorted, but revealed to me in all its stark beauty, calling up from within me my own beauty. (That is why I find that phrase in the movie Avatar, 'I see you' so powerful. To have yourself reflected back to you - in all your depth and uniqueness - is to be affirmed in your innermost being). I was no longer the ugly bastard child of the West, an American wannabe. In that firsttime encounter with the true beauty of our people, I was birthed anew, welcomed home as it were and told, it is okay to be who you are: a Pinoy, a Kapampangan, brown-skinned, a natural groupie, with tongue made for Kapampanganspeaking, not English-speaking. Malagu ka. You are beautiful.

Since then, I have, both in my scholarship and personal life, committed to learning all I can about indigenous ways of being and, with the help of teachers, to recovering my own indigenous soul. And the more I learned, the deeper I fell in love.

\section{Framing history}

But to backtrack a little and provide a fuller context to the significance of this transformative moment, I need to reprise briefly the history of relations between the Philippines and the United States. (I know that when I met my Euro-American husband who holds a doctorate degree in theology at the University of Chicago, he had known next to nothing about that history.) Unbeknownst to many, the Philippines occupies a central place in US history in that it marked the latter's initial entry into the race to superpowerdom. For in order to become a superpower, what it took was the seizing and takeover of territories for the purpose of extracting resources, enlarging one's market share, or for sheer projection of economic and military might abroad.

In the year 1898, the Philippines had just declared itself a free and independent republic after fighting a war of liberation from 350 years of Spanish rule. It was also the moment when the United States, contemplating on joining the fray for superpower land grab, made the fateful decision to seize the fledgling republic for its own colonial possession, inventing as justification the mythic narratives of Benevolent Assimilation, White Man's Burden and Manifest Destiny (cf. Horsman 1981; Jordan 1974; Miller 1982) to reconcile its projected self-image of being a freedom loving nation (which has had to fight its own war of independence) with its coveted aspiration of becoming an Empire.

No other piece of official proclamation is more emblematic of the ruses of the imperial mind than the speech of then President William McKinley to a Methodist delegation, justifying his decision to annex the Philippines and I quote:

I would like to say just a word about the Philippine business. I have been criticized a good deal about the Philippines, but don't deserve it. The truth is I didn't want the Philippines, and when they came to us, as a gift from the gods, I did not know what to do with them ... I thought at first we would take only Manila; then Luzon; then the other islands perhaps also. I walked the floor of the White House night after night until midnight; and I am not ashamed to tell you, gentlemen, that I went down on my knees and prayed Almighty God for light and guidance more than one night. And one night it came to me this way ...: (1) that we could not give them back to Spain - that would be cowardly and dishonorable; (2) that we could not turn them over to France and Germany ... - that would be bad business ...; (3) that we could not leave them to themselves - they were unfit for self-government ...; and (4) that there was nothing left for us to do but to take them all, and to educate the Filipinos, and uplift, civilize and Christianize them ... And then I went to bed, and went to sleep, and slept soundly, and the next morning I sent for the chief engineer of the War Department, and I told him to put the Philippines on the map of the United States, and there they are, and there they will stay while I am President! (Schirmer \& Shalom 1987:22-23)

Conveniently, Spain, at that point, was loathed to accept defeat at the hands of what it derisively saw as 'mere Indios'. In a face-saving move, it decided to strike up a deal with the United States in an 1898 Treaty drawn up in Paris that would have the two powers agree to hold a mock battle, by the end of which, Spain was to cede the Philippines to the United States for the price of $\$ 20$ million. The deal done, the US then proceeded to invade the Philippines in early 1899, leaving in its wake the massacre of half a million to a million Filipinos, the commission of torture and other numerous war crimes and atrocities, the burning and destruction of whole villages and the laying to waste of the country's infrastructure.

By 1902, 3 years after the fighting commenced between the United States and the Philippines, the former would declare victory, but 10 years into its formal occupation of the islands, the United States would continue to fight a protracted guerrilla war with determined Filipino revolutionaries. 
However, by the arrival of what Elliott (2005) calls, 'the second army of occupation' (p. 229), that is, the army of US civilian administrators, the Thomasite teachers, the Protestant missionaries and American Peace Corps Volunteers, conquest of the Philippine islands was effectively secured through the ensuing ideological subjugation of the populace. Brief as the US formal occupation may have been (half a century) compared to Spain's protracted regime of over three centuries, American colonialism in the end is deemed to have marked the Filipino psyche in far more lasting ways, if not more insidiously. This is because, whereas education under the Spaniards was mostly a haphazard affair concerned more with catechetical instruction, American schooling was ruthlessly systematic and efficient, inscribing the imperial, white supremacist ideology within the institution's very instruments of knowing so that anyone running through the system cannot but be, as nationalist writer Constantino (1977) puts it, 'mis-educated'.

\section{Conquest and the Christianising mission ${ }^{2}$}

The unfolding of this history in my own consciousness happened quite belatedly. As a Christian convert, for the longest time, I was a Filipino only by sheer geographic accident; in terms of worldview, I took pride in being 'nonculture-bound', allied with the transcendent Truth of God-inChrist that was purportedly unchanging, eternal and true for all times, peoples and places. Within such reckoning, any documenting of the brutality of US hegemony in our country accomplished hand-in-glove with a Christianising mission ended up being soft-pedalled, if not altogether denied, as being 'expedient' within God's sovereign plan in the world for the Philippines. And who can quarrel with God?

As it turns out, it is this suppressed history that I realised lay at the root of my self-sabotaging pathology - what postcolonial scholar Gayatri Spivak (1988) termed 'epistemic violence', the violence wrought on a people's psyche when their sense of themselves and their world is exploded through denigration, demonisation, delegitimation or simply, disallowance. As I delved further into this history, I learned that this ideology, presuming white racial superiority and that undergirded the US civilising project in the Philippines and elsewhere, pretty much wore the garb of Christian religion. Europe's supremacist identity, after all, is historically - Christian-derived, and its genocidal settling of the so-called New World, justified as God-ordained, sanctioned by the Christian 'Doctrine of Discovery' (cf. Miller 2008; Miller, Ruru, Behrendt, \& Lindberg. 2012; Newcomb 2010; Robertson 2005).

Under the sway of this racist colonial ideology, albeit now sanitised in the seemingly more race-neutral discourse of 'modernity' and 'progress', I grew up believing that Europe and the West held the status they did in the world because of some inherent superiority they possessed - either that, or for 2.Some parts of this section may be found in Mendoza $(2005 ; 2006)$. one reason or another, they were peculiarly blessed by God to rule the world - and to strive to be like them was the only way forward for backward countries such as ours.

In church and in the schools, we learned all about this strange other world - one 'far more advanced', 'more developed' and in every way 'better' than the world we Filipinos inhabited. Indeed, our entire educational system was oriented towards that other world. We came to know ourselves primarily via the view from the outside. We were told who we were, and what we were like, by outsiders who presumed to know us better than we knew ourselves. 'Never rely on others; it's a sign of weakness'. 'Learn to stand on your own two feet'. 'Let your "yes" be a "yes" and your "no", be a "no"; don't be a liar'. 'This is a duplicitous culture, people never mean what they say and say what they mean'. 'Filipinos can never be leaders; they're never on time'. 'Filipinos are lazy; they are too much predisposed to contentment'.

In church, the hymns we sang extolled God's eternal faithfulness all through summer, winter, springtime and autumn, making one wonder whether having only 'dry' and 'wet' seasons somehow took away from God's watchfulness over these tropical islands. In science classes, we were taught not to believe in ghosts - and, dutifully, we did not; we were just afraid of them. As Christians, we were made to shun 'superstitious' beliefs and the veneration of anitos or spirits in nature. I recall an esteemed Christian mentor of mine saying with pride in a bible study on Genesis that it is only within Christianity that science could have possibly flourished because for the first time, people who formerly believed that spirit beings resided in nature (and were therefore afraid to explore, dissect, investigate and experiment with impunity) now understand that spirits do not reside in trees, rocks or animals and that the true God is actually transcendent, and that his creation (gendering intended) is given to us humans to 'manage', exercise dominion over and use to his glory. No wonder Francis Bacon, the father of modern science, would encourage boldly the torture and enslavement of Nature, urging that she be put on a rack (similar to the one they used in the middle ages to torture so-called 'witches') to make her yield her secrets.

The internalisation of this colonial, nature-dominating world view is described by one Filipino scholar thus:

The moment we began to view ourselves through Western eyes, what we held sacred suddenly became worthless, our virtues were turned into vices, our strengths turned into weaknesses, and our triumphs into failures. We could no longer be proud of anything truly our own and began to regard anything native as primitive and undeveloped. Anything indigenous became a source of embarrassment and uneasiness. (De Leon in Nono 2013:27)

\section{Beginning of unravelling}

My sojourn to the United States, not by choice but under duress, brought other realisations. One is that the muchtouted American Dream that at one point, I must admit, also 
captivated my imagination is really a nightmare - built on the massacre and annihilation of $95 \%$ of an estimated 100 million native people living up and down the Americas prior to Columbus' incursion into the so-called New World in 1492, the subsequent takeover of these native peoples' territories through treachery and deceit if not outright theft, and, the killing off of between 30 and 60 million Africans and the enslaving of the 12 million remaining whose unpaid labour (estimated in today's calculus as amounting to anywhere between 1 and 5 trillion dollars) virtually produced much of the country's enormous wealth and infrastructure. Wealth, I would find out, is never an autonomous term but a relative one. In a limited planet, its singular condition of possibility is the violent appropriation of Nature's resources as well as that of other people's labour and surplus product leading inevitably to the impoverishment of the latter. The wealth creation that alone makes modern 'progress' possible, according to writer and indigenous Mayan-inspired teacher Martin Prechtel, would not have been achievable without the creation of slaves: be it the enslavement of living matter, of other humans, or of inert substance turned into labouring machines.

Notice the paradigm shift from a relationship, among indigenous peoples, with Nature as Mother, as life source, sacred and holy where you take nothing from her without giving something back to modern Christian culture's view of nature as nothing more than resource, dead matter to do with as we please. Prechtel (in Jensen 2001) tells about the case of the Mayans (those that did not go the imperial route) whose spiritual economy of the village requires that you give a gift to that which gives you life. He writes:

A knife, for instance, is a very minimal, almost primitive tool to people in a modern industrial society. But for the Mayan people, the spiritual debt that must be paid for the creation of such a tool is great. To start with, the person who is going to make the knife has to build a fire hot enough to produce coals. To pay for that, he's got to give an [offering] to the fuel, to the fire ... Once the fire is hot enough, the knife maker must smelt the iron ore out of the rock ... What's left over represents the debt, the hollowness that's been carved out of the universe by human ingenuity, and so must be refilled with human ingenuity. A ritual gift equal to the amount that was removed from the other world has to be put back to make up for the wound caused to the divine ...

There is a deity to be fed for each part of the procedure. When the knife is finished, it is called the 'tooth of earth'. It will cut wood, meat, and plants. If the necessary [offerings] have been ignored in the name of rationalism, literalism, and human superiority, it will cut humans instead. (n.p.)

\section{He concludes:}

All of those ritual gifts make the knife enormously 'expensive', and make the process quite involved and time-consuming. The need for ritual [offering for the debt incurred in taking anything from nature] makes some things too spiritually expensive to bother with. That's why the Mayans didn't invent space shuttles or shopping malls or backhoes [not because they can't]. They live as they do not because it's a romantic way to live - it's not; it's enormously hard - but because it works. (n.p.)
And indeed, this premodern paradigm (for lack of a better word), also shared by our indigenous tribal cultures in the Philippines, has been working so well for our ancestors for hundreds of thousands of years that they have not seen the need to fundamentally change it. Theirs is a circular loop of reciprocal gift giving and generosity that has effectively preserved the balance of life and honoured the holy in nature. Death itself is simply part of that cycle of giving and receiving, of feeding and someday becoming food for others. Immortality is not an aspiration; it is imperial. Rather the Goddess of Decay is the most revered of the deities because although she cannot have children of her own, yet she causes everything else to sprout.

With the advent of domestication, the revolutionary shift from hunting and gathering or living on Nature's generosity to settled agriculture, and the consequent accumulation of surplus product and the linear invention of time, a new logic of progress, human specialness, unbridled taking without giving back (because we can) and unrelenting competition for more and more and more was introduced into life on the planet. Thereafter, the new imperative of conquest, hierarchy and domination began to spread and take root and, horrifyingly, has now become the default condition of all of us modern humans (cf. Rasmussen 1996; Quinn [1992] 1995; 1996; Shepard [1973] 1998; [1982] 1998; Wells 2010; Zerzan 2005).

A new definition of human being then began to be concocted in service of the conquering syndrome. Enshrined in the language of liberalism and justified by the Christian doctrine of stewardship, work and unceasing drive to excellence 'for the glory of God', the new qualifying standards required that for anyone to be deemed human, they needed to exhibit a certain form of rationality that excluded feelings, passions and intuition; a natural desire to accumulate wealth, to enjoy a life of material comfort and to master nature; an individualistic orientation that was notbeholden to relationships of mutual interdependency with others; and finally, a possessive, acquisitive nature that issues in a belief in private ownership (Mendoza 2013; Parekh 1995).

And given that indigenous peoples lived by an entirely different ethic than these, they did not qualify as human beings and therefore may be dispossessed of their land, territories and resources with impunity.

The arbitrary naturalisation and universalisation of this liberal (and I would say, fundamentally Christian) understanding of what it means to be a human being took a very long time to accomplish, reaching its zenith only in the last 200 years of industrial civilisation and not without resistance from indigenous people around the globe. And already, it has wreaked such havoc on the planet as to make talk of collapse - and not just economic, but ecological and civilisational - a daily fare (at least among those with access to alternative media). 


\section{Indigenous re-turnings}

Yet, it is not my aim in this article to speak exclusively about this dark looming scenario; however, much I know it is already the present reality of millions of struggling people around the world - dealing with the realities of peak oil (that has now reached the manic phase of extreme drilling and exploration), climate change, species extinction, population overshoot, to name only a few - all the result of unleashing a logic of infinite growth on a finite planet, setting our now globalised modern expansionist culture on a direct collision course with Nature and the world of indigenous peoples, given that the only remaining unexploited territories in the world today are those that lie directly under their feet.

Instead, I also wanted to speak of what, in my encounter with the indigenous world of my ancestors, I have come to love, become excited and energised by, and now want to witness to in celebration of its continuing vibrancy and myriad resurrections not only in out of the way places around the world where indigenous peoples still live, but also in the hearts of modern humans hungering for a different vision of how to live differently in our severely wounded and suffering planet.

In what little space remains, I wish to share from the learnings of a Jesuit priest anthropologist friend of mine, Fr. Albert Alejo, whose own understanding of Christian missions has been radically altered by his long-standing commitment and ongoing relationships with indigenous peoples in Southern Philippines where he teaches at the Ateneo de Davao University. In an article, he wrote on popular spirituality, he defines the phenomenon primarily as an expressive form of cultural energy.

He tells of one tradition in his home province in Obando, Bulacan where 'people would offer dances especially those who ask for a child' (Alejo 2004:34). He notes that one can also ask for a partner in life; however, if one does not know the appropriate dance steps, a child might be given instead. The town fiesta where the fertility dance is performed lasts for three days. He tells the story that once, when he was in high school actively promoting the cultural event as a tourist attraction, he was with a major media outlet trying to document the event and taking photographs when he was moved to leave the ranks of spectators and join the procession instead. He reports:

In the beginning, I was too shy to move. But I saw couples wanting to get children. In the beginning they were also shy. But as we processed, we were all put in a trance. Something happened, something moved us through the body that also moved us through the community and through the color and the sounds. We were touched. And I said to myself, now I understand why this thing will not die. There is something immortal in this practice. There is something spiritual here. I wonder whether the many people, including the priests who had worked in Obando really understood it. (p. 35)

Given the power of what he just experienced, he puzzles at the glaring absence of any reference to such practices of popular spirituality in religious textbooks. Observing the same sad fate about another region's devotions, he writes:

When Our Lady of Peñafrancia is processed, the whole Naga City comes alive in a colorful devotion. And yet, nothing of this spirit occupies a page in our religious instruction. In the seminary, we mouth all this rationalist Cogito, I think therefore I am. But there could be other approaches to existence: I dance, therefore I am. We dance, therefore, we collectively exist and live as Christians. We wear colorful hats, therefore, we are alive in our faith. We shake our bodies, we sweat, and we feel the hurt and we feel the healing, and that is how we experience the Divine. My mother would always tell me, when you come back here, please bring lana or oil for my aching back, [one that is blessed], etc. Many of us have been healed in this kind of spirituality but we have been de-inculturated by our own convents or seminary, by our formators and formation programs. Some people say they do not understand Filipinos who, in their physical fatigue, still insist on walking on their knees when they pray. Why do they impose physical hardship on their bodies? I suggest this is explained by realizing that even their language is $[a]$ bodily language. The body is a language ... Their life is the life of their body. Their happiness, fatigue and rest is their body

... That is their language. That is how they communicate. (p. 39)

In the recent launch of our book, Back from the Crocodile's Belly, I remarked as well on the lack of bifurcation in our indigenous cultures between the sacred and the profane, and between what we normally think of as good and evil.

I noted, for example, the dual signification of the crocodile in popular discourse as, on the one hand, a devouring and insatiable beast (and even now used in editorial cartoons and protest rallies to symbolise the obscene greed in the recent pork barrel scandal in our homeland) and, on the other hand, our reference to it in this book as, in fact, the Crocodile God fit to receive and be given offerings and our task as that of taking up the sacred work of singing and storying the fragments of indigenous memory back into remembrance and wholeness, of coaxing the Crocodile God to give up the pieces of the bodies of the babaylan healers he has swallowed in exchange for our offerings of grief, beauty and eloquence.

Here, the representation of the Crocodile as both a devouring god and a life-giving resurrection womb calls to mind the figure of Mama Drago, resonant in Scythian myths, as well as Celtic, and other ancient Indo-European cultures, as being in fact a figure of the Earth Mother, the source of all life, ungrudgingly supplying her children with nourishment and abundance provided she is fed, in turn, by her children's offerings of human ingenuity with grief and remembrance. But the same nurturing Mother becomes a hungry devouring beast when denied her due (as we witness today in the denying of her waters in drought, or in the similar withdrawing of fertility from her soils, or her thundering response to human expansionist folly in the catastrophic floodings, tornados and forest fires that increasingly have become the norm across the globe).

Similarly, indigenous cultures believe that ancestors, too, become hungry ghosts when not fed offerings of grief, beauty 
and eloquence, for, as writer Martin Prechtel notes, unlike our more distant and intact forebears, 'our [more recent] ancestors weren't necessarily very smart. In many cases, they are the ones who left us this mess. Some of them were great, but others had huge prejudices'. (in Jensen 2001).

Thus, we feed and heal them with our offerings, lest they remain hungry ghosts, unable to take their rightful place as ancestors, causing us to live out their prejudices in our lifetime, and creating cultures ridden with depression, violence and despair.

The beauty I see in this way of reckoning is that rather than the constant separation of good versus evil and the search for purification via religions of exorcism and demonisation, we witness instead relationships of mutuality and honouring, of giving and receiving, of offering to the Other World what is its due and receiving from it with abundant gratitude. As Alejo (2004) writes, remarking on the evangelical practice of a small group of believers at the back of their Jesuit house of constantly exorcising and rebuking devils every weekend at their worship services:

In contrast, I have witnessed many tribal rituals. In the mountains, there are also many spirits, some benevolent, some malicious, and some simply hungry. What do the tribal baylans do? In different forms, in different ways, they would reserve some food for the malignant spirits. 'There is food for you here. Please don't bother us because we are going to have a special event. Please, do not go beyond this line.' This 'pasintabi' [or respectfully asking for permission] has many names in different ethnic groups. The idea is that we negotiate with the spirits. We don't shout at them. We don't rebuke them. I think that, in general, that is a better way to deal with spirits. (p. 45)

For me, this journey of allowing myself to be taught by the spirit of our ancestors has been both humbling and exhilarating. In my other academic writings, I have begun to refer to it as 'a love story' (Mendoza 2016 from the essay title). For, as we wrote in our Crocodile book, 'it is not enough to see and grieve what is wrong in the world; one needs also to fall in love' (Mendoza \& Strobel 2013:8). Indeed, discovering the world of our ancestors - 'before the invention of violent hierarchies and the beauty-killing empires, machines, markets, standing armies, corporations, and governments that now threaten our world' (p. ii) - is like being born anew into a new world. A world full of wonder, mystery and so much more humanity, so different from the depressing one we live in today - full of hungry ghosts, unmourned dead and medicated casualties of modern civilisation.

In summarising his reflections on popular spirituality (and I am using the term loosely here as a kind of spirituality that still retains the memory of an older, more ancient indigenous spirituality), Fr. Alejo concludes that this kind of spirituality is not a rejection of other ways of practicing spirituality; it is simply:

an expression of a particular way of being human, a particular way of connecting to the Divine. It is the energy to be themselves [ a way of celebrating who they are]. It is a spirituality of the body not of abstracted essence of the spirit. It is a spirituality of the many, not of the soloist individual. It is a spirituality of celebration, and never of denial of the self or of the world. It is also a spirituality of [meaning and] negotiation, not of [dogma or doctrine]. (p. 46)

In the olden days when my life's purpose as a Christian was about 'bringing everyone to the fold under the banner of Christ', whenever I encountered anyone of a different faith, no matter my attempts at dialogue, cultural sensitivity or compassionately opening up to the 'truths' of the other's faith tradition, in the end, I always had the trump card up my sleeve. As Filipino thinker, scholar and Christian writer Melba Maggay (2011) cannot help but conclude even after her excellently nuanced analysis of the cultural faux pas of the early Protestant missionaries in the Philippines in her book, A Clash of Cultures:

We need to wrestle with our own culture at its point of greatest power and peril if we are to bring it under the light of Christ. Only then can we presume to say something about the uniqueness and superiority of Christ to the great cultures around us. (p. 198, [author's own italics])

Meaning, cut through the smoke and mirrors, the goal in devoting all that effort to understanding the indigenous culture was finally, simply one more time, to more effectively bring Filipinos under the superior sign of Christ.

For much of my adult life, I was myself the articulator of this supremacy that ironically was ultimately doing damage to me. And for 20 years now, my work has been to pursue relentlessly the grip of that superiority on my own soul and its reach into the culture of my people in order to undo its damaging denigration and recover a much bigger and more indigenous sense of God and spirit in my life.

So, the question I ask is the following: What if, as Christians, we were to humbly lay down the trump card, take genuine curiosity in others not just for the purpose of missionising them better, but to really listen and learn from what they have to teach us from their own truths? Are we willing to let our Christian story take its place as only one - worthy as it is among many other true stories in a posture of mutual giving and cocreation of a future we can all share?

\section{Acknowledgements Competing interests}

The author declares that he or she has no financial or personal relationships which may have inappropriately influenced him or her in writing this article.

\section{References}

Alejo, A., 2004, 'Popular spirituality as cultural energy', in Lecture series 3 on spirituality: Context and expressions of Filipino spirituality, pp. 33-52, Center for Spirituality-Manila, Quezon City, Philippines.

Constantino, R., 1977, 'The miseducation of the Filipino', in C.N. Lumbera \& T. Gimenez-Maceda (eds.), Rediscovery: Essays in Philippine life and culture, pp. 125-145, Department of English, Ateneo de Manila and National Book Store, Inc., Quezon City.

Elliott, C.B., 2005, The Philippines, University of Michigan Library, Ann Arbor, MI. 
Horsman, R., 1981, Race and manifest destiny: Origins of American racial AngloSaxonism, Harvard University Press, Cambridge, MA

Jensen, D., 2001, 'Saving the indigenous soul: An interview with Martin Prechtel', The Sun Magazine, viewed 08 May 2017, from http://thesunmagazine.org/ issues/304/saving_the_indigenous_soul

Jordan, W.D., 1974, The white man's burden: Historical origins of racism in the United States, Oxford University Press, New York.

Kraft, C., 1979, Christianity in culture: A study in dynamic biblical theologizing in crosscultural perspective, Orbis Books, Maryknoll, NY.

Kremer, J.W., 2003, 'Ethnoautobiography as practice of radical presence', ReVision 26(2), 4-11.

Kremer, J.W. \& Jackson-Paton, R., 2014, Ethnoautobiography: Stories and practices for unlearning whiteness, decolonization, uncovering ethnicities, Re-Vision Publishing, Sebastopol, CA.

Maggay, M.P., 2011, A clash of cultures: Early American Protestant missions and Filipino religious consciousness, Anvil Publishing, Inc., for De La Salle University, Manila.

Mendoza, S.L., 2005/2006, 'Tears in the archive: Creating memory to survive and contest empire', in R. Lustig \& J. Koester (eds.), Among US: Essays on identity, belonging, and intercultural competence, rev. edn., pp. 233-245, Pearson, Boston, belong

Mendoza, S.L., 2013, 'Savage representations in the discourse of modernity: Libera ideology and the impossibility of nativist longing', Decolonization, Indigenization, Education, and Society 2(1), 1-19.

Mendoza, S.L., 2016, 'Out of modernity into deep ancestry: A love story', in K. Sorrels \& S. Sekimoto (eds.), Globalizing intercultural communication, pp. 44-55, Sage, Thousand Oaks, CA.

Mendoza, S.L. \& Kinefuchi, E., 2016, 'Two stories, one vision: A plea for an ecological turn in intercultural communication', Journal of International and Intercultural Communication 9(4), 275-294. https://doi.org/10.1080/17513057.2016.1225451

Mendoza, S.L. \& Strobel, L. M. (eds.), 2013, Back from the crocodile's belly: Philippine Babaylan studies and the struggle for indigenous memory, Center for Babaylan Studies, Santa Rosa, CA.

Miller, R.J., 2008, Native America, discovered and conquered: Thomas Jefferson, Lewis \& Clark, and Manifest Destiny, University of Nebraska Press, Lincoln, NE.
Miller, R.J., Ruru, J., Behrendt, L. \& Lindberg, T., 2012, Discovering indigenous lands: The Doctrine of Discovery in the English colonies, Oxford University Press, Oxford

Miller, S.C., 1982, 'Benevolent assimilation': The American conquest of the Philippines, 1899-1903, Yale University Press, New Haven, CT.

Newcomb, S.T., 2010. The legacy of fifteenth century religious prejudice, Cross-cultura Shamanism Network, Willits, California.

Nida, E. \& Taber, C.R., 1969, The theory and practice of translation, Brill, Leiden.

Nono, G., 2013, Song of the babaylan: Living voices, medicines, spiritualities of Philippine ritualist-oralist-healers, Institute of Spirituality in Asia, Quezon City, Philippines.

Parekh, B., 1995, 'Liberalism and colonialism: A critique of Locke \& Mill', in J.N. Pieterse \& B. Parekh (eds.), Decolonization of imagination: Culture, knowledge and power, pp. 81-98, Zed Books, London.

Quinn, D., 1992/1996, Ishmael, Bantam Books, New York.

Quinn, D., 1996, The story of B, Bantam Books, New York.

Rasmussen, L., 1996, Earth, community, earth ethics, WCC Publications, Geneva.

Robertson, L.G., 2005, Conquest by law: How the discovery of America dispossessed indigenous peoples of their land, Oxford University Press, New York.

Schirmer, D.B. \& Shalom, S.R. (eds.), 1987, The Philippines reader: A history of colonialism, neocolonialism, dictatorship, and resistance, South End Press, Boston, MA.

Shepard, P., 1998, 'A Post-Historic Primitivism', in J. Gowdy (ed.), Limited wants, unlimited means, pp. 281-328, Island Press, Washington, DC

Shepard, P., 1973/1998, The tender carnivore and the sacred game, The University of Georgia Press, Athens, GA.

Shepard, P., 1982/1998, Nature and madness, The University of Georgia Press, Athens, GA.

Spivak, G.C., 1988, 'Can the subaltern speak?', in C. Nelson \& L. Grossberg (eds.), Marxism and the interpretation of culture, pp. 271-313, University of Illinois Press, Champaign, IL.

Wells, S., 2010, Pandora's Seed: The unforeseen cost of civilization, Random House, New York, NY.

Zerzan, J. (ed.), 2005, Against civilization, Feral House, Los Angeles, CA. 